\title{
Assess Experimental Use Fractionation Column on Distillation System Liquid Smoke as Preservatives Food of Coconut Fiber
}

\author{
Johannes Munintja Mawa ${ }^{1, *}$, Artian Sirun ${ }^{1}$, Georis Judri Fontje Kaligis ${ }^{2}$ \\ ${ }^{1}$ Department of Mechanical Engineering, Manado State Polytechnic, Indonesia \\ ${ }^{2}$ Faculty of Fisheries Manado, Sam Ratulangi University, Indonesia
}

Copyright $(0) 2015$ Horizon Research Publishing All rights reserved.

\begin{abstract}
In Indonesia in general has the potential of natural resources are very abundant, especially in North Sulawesi are famous with waving palm earth this is due in North Sulawesi has great natural resources, especially oil. The potential of these highly abundant palm plantations should be empowered to optimally especially waste handling, especially coco. Coconut coir that has been processed in the pyrolysis contains substances such as cellulose, hemicellulose and lignin that are useful in the management and preservation of food more specifically for marine fish preservation, especially in the process of replacement of smoked fish. Because of the usefulness of these substances, then we make a distillation system which can generate smoke condensate liquid through the combustion process called pyrolysis fractionation column by using the function captures tar to avoid ending up in the smoke which is condensed into liquid smoke. This study aims to (1) Make distillation system liquid smoke from coconut husk using a fractionating column of stainless steel metal materials (2) evaluating the need for heat in the distillation system liquid smoke from coconut husk (3) Conduct a study experimentally liquid smoke from coconut husk as food preservative, especially fish. Coco fiber $20 \mathrm{~kg}$, through the pyrolysis process within 20 minutes resulted in $7.5 \mathrm{~kg}$ of liquid smoke. The research was conducted at the Department of Mechanical Engineering workshop Manado State Polytechnic.
\end{abstract}

Keywords Coconut Fiber, Liquid Smoke, Fractionation Column

\section{Introduction}

North Sulawesi since the last few years has seen an increase in various fields such as agriculture, fisheries, services, trade, tourism and education.

In line with government policy to implement infrastructure development in fields mentioned are concerned, national and foreign private sector is also actively involved in investing and business development in North Sulawesi.

North Sulawesi (Sulawesi) has been known area rich in natural resources, especially coconut, nutmeg, cloves, palm and others. In this particular case are very abundant palm trees, although not optimal yet empowered with the needs of an increasingly larger than their role needs to be optimized.

To optimize the natural resources it needs instensif management, one of which is the manufacture of liquid smoke as a food preservative khusnya sea fish. whereas the raw materials used for the manufacture of liquid smoke, among others, various types of wood, shell or the other of the oil, pulp, husks, sawdust and other wood.

In this case the use of coco which have been considered as waste in order to be useful, if the beneficiaries of coco in liquid smoke up into the pyrolysis process, liquid smoke is a result of condensation or smoke condensation heating or direct combustion of materials many contain cellulose, lignin, hemicellulose and other carbon compounds from the distillation system.

Liquid smoke from coconut husk-containing substances such as cellulose, hemicellulose and lignin useful for food preservation especially sea fish in this liquid smoke as a substitute for the smoking process. Basically liquid smoke can be utilized to preserve all types of food such as fish, meatballs, cakes, and fruit.

In this research, modifications prior distillation system by adding the fractionation column. The fractionation column serves to inhibit / catch tar so as not to participate in the smoke to be condensed into liquid smoke.

With this study are expected to use liquid smoke from the coconut husk which is the source of natural antioxidants in food products more specifically the results of marine fish is a mainstay located in North Sulawesi. During this traders and reservoir fishing results to preserve fish with ice cubes this increases the cost of preservation, but with the use of liquid smoke can reduce the cost for fish preservation . 
The grounds and the description above, this research entitled:

"Assess Experimental Use Fractionation Column Distillation System Liquid Smoke On As Preservatives Coconut Fiber Foods".

\section{Materials and Methods}

\subsection{Materials Used}

The materials used to make the distillation system is made of stainless steel plate and pipe, ss welding wire, welding wire RB 6013, a large chunk grinding stone, stone cutting and Sharpener grinding, sandpaper, green stone, polishing cloth, bolts and nuts, while materials needed for the cooling system, among others, pumps, drums, PVC pipe, faucet, frame buffer drums, and other materials needed.

\subsection{Equipment Used}

The equipment used in this study include: welding machine, $\mathrm{O} 2$ gas, argon gas, cutting machine, roll machine, drilling machine, grinding machine, drill bits, roll meter, ruler, hammer, steel pointer, steel ruler, handsaw, steel chisel, thermometers, manometers and other water needs. While other equipment needed to make the system available in the engine shop distillation Department of Mechanical Engineering State Polytechnic Manado. For the location of our distillation system testing done within the State polytechnic Manado to create a simple building with the use of materials, namely: wood, zinc, cement, sand, red rocks and other needs.

\subsection{Methods}

To know the process of making good quality liquid smoke is by doing research on the assessment of the distillation system.

\subsubsection{Place and Time Research}

Where the research conducted within the Department of Mechanical Engineering State Polytechnic Manado and timing of research tailored to the user / budgeting of Prime Research Universities. Planned for 3 years (2014, 2016, 2017).

\subsubsection{Type Research.}

a. Observation (field survey), conducted to obtain information on how to manufacture liquid condensate (liquid smoke).

b. Create, design and manufacture of system installation distillation of liquid smoke.

c. Studies Reader, necessary to evaluate the results obtained with the problems studied.

\subsection{Data Source Required}

The data is information that is required in the completion of this study is that the data obtained directly through observation and testing of the system, namely distillation of liquid smoke: study room temperature, the temperature inside the reactor before it is heated, the temperature of cooling water in and out of the condenser, the condenser exit temperature masukdan smoke, volume of condensate (liquid smoke) after completion of combustion, combustion products coco volume of the reactor.

\subsection{Stages Making Distillation System}

The research to be carried out with the following stages: the manufacture of distillation systems, distillation systems made testing and feasibility analysis of the product. In the first year of researchers focused on making distillation system to determine the parameters to optimize results and redesign distillation system based on previous research. While in the second year Researchers will conduct a review of the experimental system on distillation to Obtain product performance and results Obtained an overall picture of the development of distillation systems are made .

\subsection{Testing Distillation System}

To determine the performance of the distillation system can be operated with either the operation procedure can be performed as follows:

1. Prepare raw materials coco, weighed and then insert it into the reactor and inlet cap tightly.

2. Turn on the pump that circulates cooling water to the condenser container

3. Turn on the fire on the stove to heat the water heater.

4. Conducting observations measuring tools, namely: temperature measuring instruments, pressure gauge, Time (hours) and tidal gauge glass liquid smoke fluid reservoir and observation and data recording.

\subsection{The Method of Analysis}

\subsubsection{Pyrolysis process}

Pyrolysis is the chemical decomposition of organic material through a heating process with little or no oxygen or other reagents, in which raw materials will undergo chemical structure solution into the gas phase, but if the gas is cooled it will form a liquid.

During the heating or combustion process, the components of the material being burned will undergo pyrolysis which produces a wide variety of other phenolic compounds , acids , hydrocarbons , carbonyl, furan, alcohol , lakton polisiklik, aromatic and others .

\subsubsection{Heat}

In the science of thermodynamics, heat can be defined as a form of energy that can be transferred across the boundary of a system at a given temperature in the form of another system at a given temperature which is lower due to temperature 
differences.

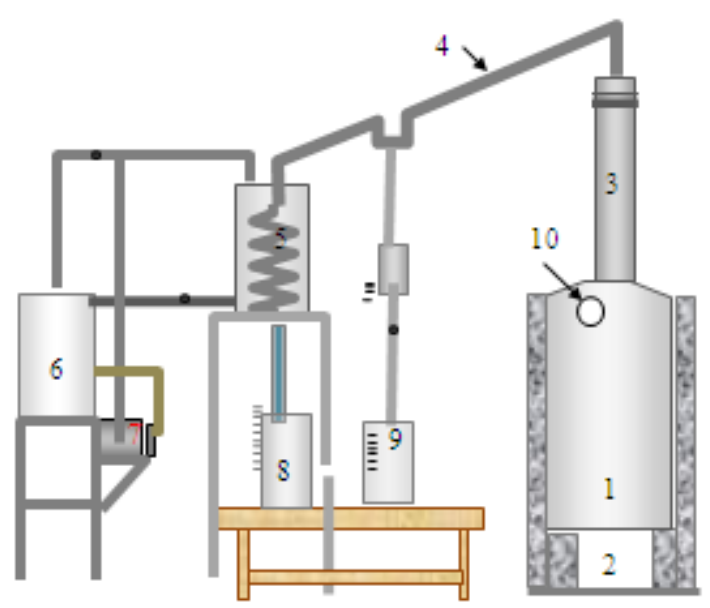

caption :

1. Reactor

2. Furnace

3. Fractionation Column

4. Steam Pipeline Tar

5. Condenser
6. Coolant Tank
7. Pump
8. Containers of liquid smoke
9. Tar Receiver
10. Measuring Temperature

Figure 1. Plan for system design distillation of liquid smoke with column fractionation

Calor is the trajectory function / process (as well as the initial and final conditions), because it differential denoted $\partial \mathrm{Q}$ and when in the integral, becomes $\int \partial \mathrm{Q}={ }_{1} \mathrm{Q}_{2}$ means of heat transferred during the process of 1 to 2 with units of Joules $(\mathrm{J})$, whereas the rate of displacement heat of a system can be expressed by the equation:

$$
\mathrm{Q}=\partial \mathrm{Q} / \mathrm{d}_{\mathrm{t}}(\mathrm{W}) \text { or }(\mathrm{kW})
$$

\subsubsection{Concept of Heat Transfer}

Heat transfer is an energy transfer from the other systems as a result of the temperature difference between the systems. The energy is transferred in the form of heat, so the heat flow will occur. So the science of heat transfer is the main target transfer rate. Heat transfer itself is where there is a temperature gradient in a fluid or other solid material, it will naturally or in a condition of forced heat will move.

\subsubsection{In Convection Heat Transfer}

Convection heat transfer occurs when heat travels or moves from a high temperature to a lower temperature region. If the fluid motion occurs due to the help of a blower or pump, it is called forced convection, while the natural convection occurs because of differences in the density of the fluid. To this can be calculated by the formula:

$$
\mathrm{q}_{\mathrm{h}}=\overline{\mathrm{h}} \cdot \mathrm{A}_{\mathrm{s}}\left(\mathrm{T}_{\mathrm{s}}-\mathrm{T}_{\infty}\right)
$$

\subsubsection{Heat conduction}

Conduction is the process of heat transfer from the high temperature to low temperature area in a solid or plated directly without mass transfer.

How to conduction heat transfer by French scientists
JBJFourier, 1882 stated that, the rate of heat flow by conduction in a material way, equal to the product of the three following scale:

- Heat conduction in flat plate :

$$
\mathrm{q}_{\mathrm{k}}=-\mathrm{k} \cdot \mathrm{A} \cdot \frac{\mathrm{dT}}{\mathrm{dx}}
$$

\subsubsection{Heat Exchanger Equipment}

This heat exchanger is used to cool or condense steam or vapor mixture, thus changing into a liquid phase. Cooling medium used is water, steam will then release the latent heat to the coolant.

The condenser is a device in which the heat transfer fluid temperature from a higher to a lower temperature. The condenser is planned indirect condenser (indirect contact), where the hot fluid is not directly related to the cold fluid. Heat transfer process has its medium, such as pipes, plates or other types of equipment.

- $\quad$ Difference in average temperature :

$$
\operatorname{LMTD}=\overline{\Delta T}_{\text {LMTD }}=\frac{\Delta \mathrm{T}_{\mathrm{a}}-\Delta \mathrm{T}_{\mathrm{b}}}{\ln \left(\frac{\Delta \mathrm{T}_{\mathrm{a}}}{\Delta \mathrm{T}_{\mathrm{b}}}\right)}
$$

- Overall heat transfer in a heat exchanger

$$
\mathrm{Q}=\mathrm{A}_{\mathrm{s}} \mathrm{x} \mathrm{U} \times \mathrm{LMTD}
$$

\subsubsection{Pipeline Steam / Smoke}

Pipeline serves to drain the steam / smoke so as not to come out, while the design of the pipeline is shaped like the image that is made in such a way in order to function optimally so that the smoke flows into the condenser which would then be condensed into liquid smoke. While tar will first melt because its density is greater than the liquid smoke hereinafter tar tar out through the channel.

\section{Results and Discussion}

\subsection{Results of Analysis of Distillation Systems}

Data and results of the planning and design of distillation systems are:

Dimensions burner reactor made cylindrical shape with volume are:

$$
\begin{gathered}
\mathrm{V}=\frac{\pi(D-d)^{2} L}{4} \\
=\frac{3.14(0.630-0.2)^{2} 1}{4}=0.145 \mathrm{~m}^{3}
\end{gathered}
$$

Large heat removed / disposed along the tube are:

Cylindrical reactor tube of length $\mathrm{L}=1 \mathrm{~m}$ in diameter in at $=0.630 \mathrm{~m}$ thick plate of stainless steel tube $\mathrm{t}=2 \mathrm{~mm}(0.002$ $\mathrm{m})$ and the outer diameter do $=0634 \mathrm{~m}$ with thermal conductivity $(\mathrm{K})=16 \mathrm{~W} / \mathrm{m} \mathrm{K}$,

Heat transfer coefficient on the inside of the tube is: 


$$
\begin{gathered}
\mathrm{h}_{\mathrm{i}}=3.66 \frac{\mathrm{k}}{\mathrm{d}_{\mathrm{i}}} \\
\mathrm{h}_{\mathrm{i}}=3.66 \frac{1.54}{0.630}=8.95 \mathrm{~W} / \mathrm{m}^{2} \mathrm{~K}
\end{gathered}
$$

Heat transfer coefficient on the outside of the tube

$$
\begin{gathered}
\mathrm{h}_{\mathrm{o}}=3.66 \frac{\mathrm{k}}{\mathrm{d}_{\mathrm{o}}} 1 \\
\mathrm{~h}_{\mathrm{o}}=3.66 \frac{0.02631}{0.634}=0.152 \mathrm{~W} / \mathrm{m}^{2} \mathrm{~K}
\end{gathered}
$$

Calculation of heat transfer coefficient (Uo) is:

$$
\mathrm{U}_{\mathrm{o}}=\frac{1}{\left(\mathrm{~d}_{\mathrm{o}} / \mathrm{d}_{\mathrm{i}}\right)\left(1 / \mathrm{h}_{\mathrm{i}}\right)+[1 /(2 \mathrm{k})] \mathrm{d}_{\mathrm{o}} \ln \left(\mathrm{d}_{\mathrm{o}} / \mathrm{d}_{\mathrm{i}}\right)+\left(1 / \mathrm{h}_{\mathrm{o}}\right)}
$$

from the above equation is obtained:

$$
\mathrm{U}_{\mathrm{o}}=0.205 \mathrm{~W} / \mathrm{m}^{2} \mathrm{~K}
$$

Sectional area of the flow tube reactor

$$
\begin{gathered}
A_{t}=\pi d_{o} L \\
=3.14 \times 0.634 \times 1=1.992 \mathrm{~m}^{2}
\end{gathered}
$$

Broad Cross-Sectional Flow Shell condenser is:

$$
\begin{gathered}
\mathrm{A}_{\mathrm{s}}=\pi \mathrm{d}_{\mathrm{i}} \mathrm{L}-\Pi \mathrm{d}_{\mathrm{o}} \mathrm{L} \\
=3.14 \times 0.1016 \times 0.60-3.14 \times 0.0150 \times 0.60 \\
\mathrm{~A}_{\mathrm{s}}=0.163 \mathrm{~m}^{2}
\end{gathered}
$$

\subsection{Testing Results Distillation System}

In this process the coconut husk through the combustion process as much as $20 \mathrm{~kg}$ and the heating process time is 70 minutes. While the amount of liquid smoke produced is $7,500 \mathrm{~g}$. From the observation of researchers paint test results and obtain the data in Table 1 and the carrying out of the picture graph shows that as the increase in the combustion temperature, the temperature is hyperbolic. This is because the process of thermal degradation of the reactor began in the heating process and ends with the heating process no longer occur because the coconut husk charcoal has become no longer thermally degraded.

The pictures below are addressing the coconut husk combustion process temperature with time burning.

From Figure 5 it appears that many liquid smoke obtained in the process of 20 to 40 minutes burning time this is due to the content of the smoke on coco on many degraded thermal reactor in the process condition, while over time increases

\begin{tabular}{|c|c|c|c|c|c|c|}
\hline $\begin{array}{l}\text { Burning } \\
\text { Time } \\
\text { (min) }\end{array}$ & $\begin{array}{l}\text { Temperature } \\
\text { Reactor } \\
\mathrm{T}_{1}\left({ }^{\circ} \mathrm{C}\right)\end{array}$ & $\begin{array}{l}\text { Smoke sign } \\
\text { condenser } \\
\text { temperature } \\
\mathrm{T}_{2}\left({ }^{\circ} \mathrm{C}\right)\end{array}$ & $\begin{array}{l}\text { Condenser } \\
\text { Temperature } \\
\text { Liquid Smoke } \\
\text { Out } T_{3}\left({ }^{\circ} \mathrm{C}\right)\end{array}$ & $\begin{array}{l}\text { Sign } \\
\text { condenser } \\
\text { water } \\
\text { temperature } \\
\mathrm{T}_{4}\left({ }^{\circ} \mathrm{C}\right)\end{array}$ & $\begin{array}{l}\text { Condenser } \\
\text { Water } \\
\text { Temperature } \\
\text { Out } \mathrm{T}_{5}\left({ }^{\circ} \mathrm{C}\right)\end{array}$ & $\begin{array}{l}\text { Results } \\
\text { liquid } \\
\text { condensate } \\
\text { (liquid } \\
\text { smoke) (g) }\end{array}$ \\
\hline 0 & 0 & 28 & 28 & 29 & 29 & 0 \\
\hline 10 & 74 & 29 & 28 & 29 & 29 & 600 \\
\hline 20 & 124 & 48 & 40 & 29 & 30 & 1,500 \\
\hline 30 & 159 & 62 & 51 & 30 & 32 & 2,200 \\
\hline 40 & 198 & 77 & 63 & 31 & 34 & 1,680 \\
\hline 50 & 228 & 89 & 73 & 33 & 37 & 830 \\
\hline 60 & 247 & 96 & 79 & 35 & 39 & 450 \\
\hline 70 & 252 & 98 & 81 & 38 & 42 & 240 \\
\hline \multicolumn{6}{|c|}{ Acquisition amount of liquid smoke } & 7,500 \\
\hline
\end{tabular}
the content of the smoke in the combustion process decreases so that liquid smoke the resulting reduced. This is due to the coco has burned completely.

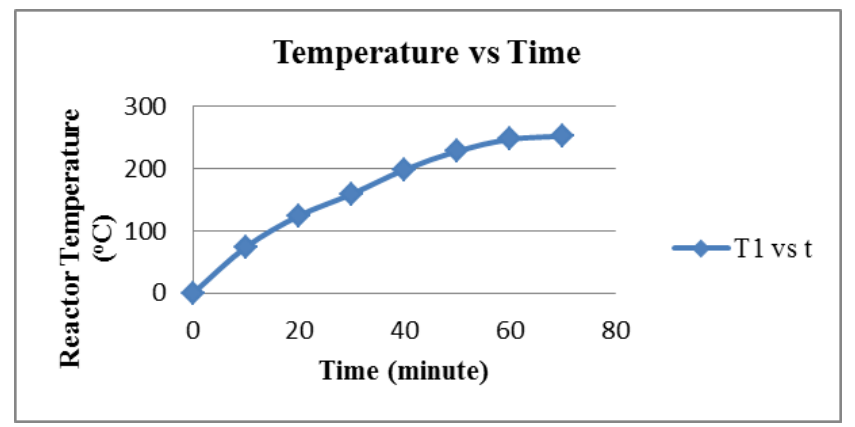

Figure 2. temperature vs Time (minute) combustion in the reactor.

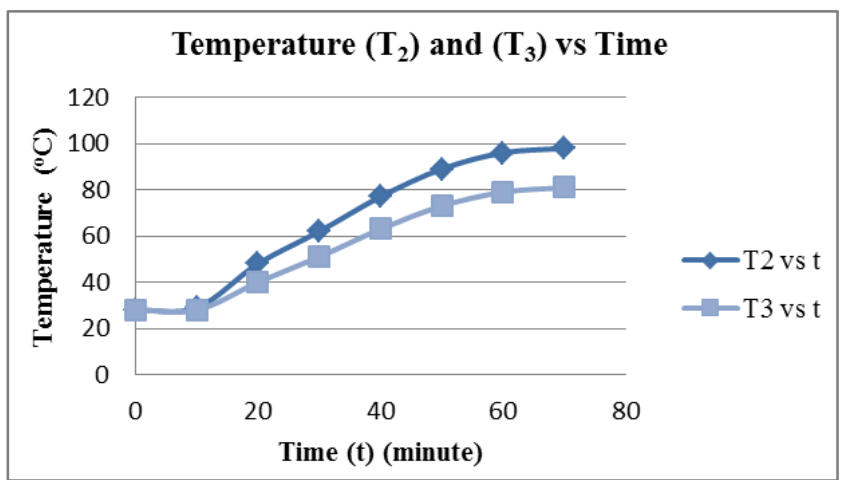

Figure 3. Temperature smoke enters the condenser (T2) and the condenser exit temperature of liquid smoke (T3) vs. Time (minute) Combustion

Table 1. Data Observation Process Testing 


\section{Conclusions and Recommendations}

\subsection{Conclusions}

This study starts from the planning, design to manufacture liquid smoke distillation system with stainless steel and experimentally assess distillation system made by pyrolysis. From the results of the study for pyrolysis coco fiber $20 \mathrm{~kg}$ with a duration of 70 minutes resulted in as many as 7,500 g of liquid smoke.

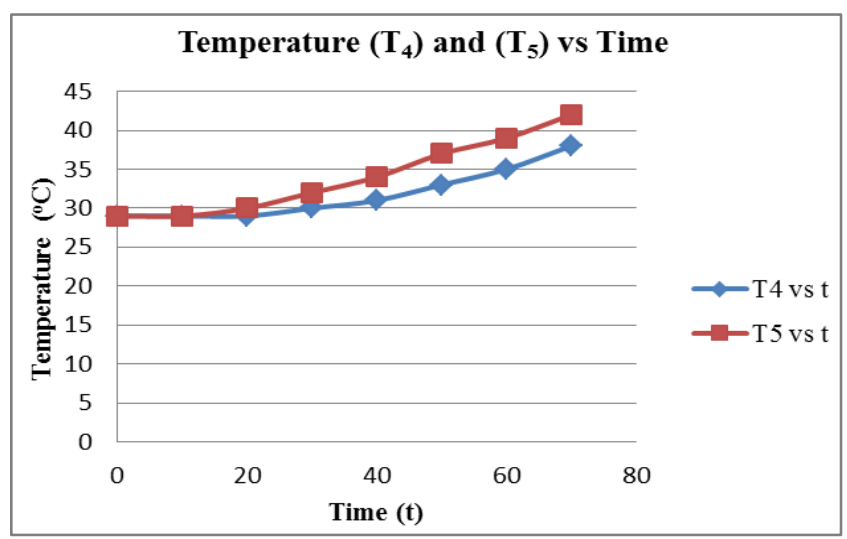

Figure 4. entering condenser cooling water temperature (T4) and exit condenser cooling water temperature (T5) vs. Time Combustion

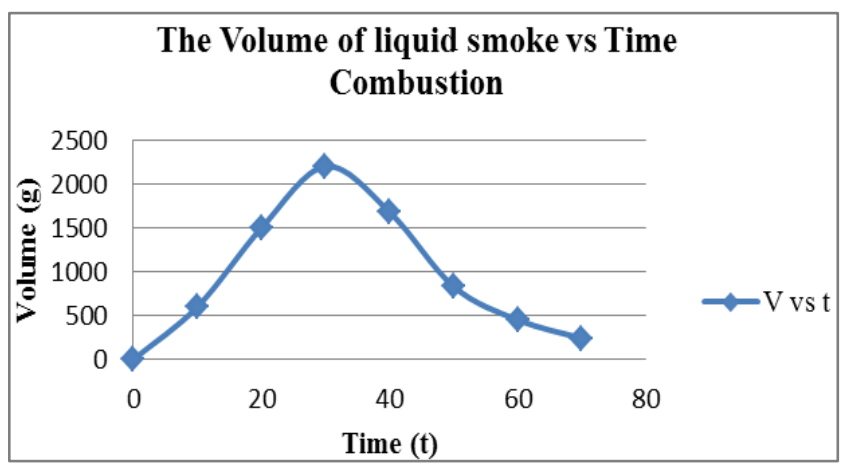

Figure 5. The volume of liquid smoke obtained vs. Time combustion

\subsection{Suggestions}

Things that need to be considered in planning, designing and manufacturing must be really careful to produce a distillation system with a good fractionation column.

\section{REFERENCES}

[1] Darmadji, P, Benzopyren levels pruduk-Traditional Asapan Products. Proceedings of the National Seminar on Food Tradicional. Jayakarta Hotel, Yogyakarta. 1996

[2] J. P. Holman, , Heat Transfer, Sixth Edition. translation by E. Jasjfi M.Sc. Erlangga, Jakarta, 1988.

[3] M. Necati Ozisik, 1985, Heat Transfer, McGraw-Hill Book Company.

[4] Mansur.Yogyakarta Integrated Coconut Processing. Coconut home Indonesia, 2013.

[5] Perry's, Chemical Engginer Hand Book, Seventh Edition McGraw-Hill Companies, Inc. 1990.

[6] Robert C.Reid, Jhon M. Prausnitz, Bruce E Poling. 1988. The Properties of Gasess \& Liquids. Mc Graw-Hill, Singapore

[7] Sadik Kakac Hongtan Liu, Heat Exchangers, Departement of Mechanical Engineering University of Miami Coral Gables, Frorida. 1998.

[8] Suharto, Food Preservation Technology, Rineka Cipta, Malang, 1991.

[9] Sutin, Making Liquid Smoke From Shell and Coconut Fiber In Pyrolysis And Fraksinasinya. 2008.

[10] William C. Reynolds and Henry C. Perkins, 1989 ENGINEERING THERMODYNAMICS. Issue 2, Translation by C. Filino Harahap, Erlangga, Jakarta.

[11] http://repository.ipb.ac.id/bitstream/handle/123456789/ 13805/F08sut.pdf 